\title{
Pendampingan Pembuatan Laporan Keuangan Pelaku Usaha Kecil Di Desa Pengulu Kecamatan Sidayu Kabupaten Gresik Menjadi Bankable
}

\author{
Siti Samsiyah ${ }^{1}$, Fachrudy Asj'ari $^{2}$, Edy Sulistyawan ${ }^{3,}$ Yuli Kurnia Firdausia ${ }^{4}$ \\ ${ }^{123}$ Program Studi Manajamen, Fakultas Ekonomi, Universitas PGRI Adi Buana Surabaya \\ ${ }^{4}$ Program Studi Akuntansi, Fakultas Ekonomi, Universitas PGRI Adi Buana Surabaya \\ Email :sam.si29@yahoo.co.id
}

\begin{abstract}
ABSTRAK
Tujuan kegiatan pengabdian kepada masyarakat ini adalah memberikan pengatahuan dan ketrampilan kepada usaha kecil dan masyarakat desa Pengulu Kecamatan Sidayu Kabupaten Gresik. Metode pelaksanaan adalah pendampingan laporan keuangan, tim pelaksana melakukan kegiatan ini memfokuskan pada peningkatan pengetahuan dasar tentang penyusunan laporan keuangan sederhana, dan bekerja sama dengan perbankan untuk menambahkan modal usaha. Pendampingan dilaksanakan dengan materi pembukuan dan penyusunan sistem akuntansi dan keuangan pada pengusaha kecil. Kegiatan ini diharapkan dapat mensosialisasikan hasil simulasi tentang pembukuan dan penyusunan laporan keuangan sebagai wujud pengabdian pada masyarakat. Untuk mengetahui wujud keberhasilan pengbdian pada masyarakat, identifikasi keberhasilan adalah apabila pengusaha kecil dapat membuat laporan keuangan yang baik dan menyusun laporan sesuai format yang ada. Pelaku Usaha Kecil Menengah (UKM) yang ingin menggunakan prinsip laporan keuangan untuk menyediakan informasi tentang posisi keuangan, kerja keuangan, laporan arus kas. Usaha ini akan berpengaruh dengan modal awal untuk pengembangan usaha tersebut, dan bekerja sama dengan bankable syaratnya yaitu disiplin. Disiplin dalam hal pencatatan baik usaha financial maupun pencatatan legalitas usaha.
\end{abstract}

Kata Kunci : Laporan Keuangan, Pelaku Usaha, Gresik

\begin{abstract}
The purpose of community service activities is to provide knowledge and skills to small businesses and the community of Pengulu village, Sidayu District, Gresik Regency. The implementation method is the accompanying financial statements, the implementation team conducted this activity focusing on increasing basic knowledge about preparing simple financial statements, and working with banks to add venture capital. Assistance is carried out with bookkeeping material and preparation of accounting and financial systems for small entrepreneurs. This activity is expected to be able to disseminate the results of simulations about bookkeeping and preparation of financial statements as a form of community service. To find out the form of success in serving the community, identification of success is when small entrepreneurs can make good financial reports and compile reports according to existing formats. Small and Medium Enterprises (SMEs) who want to use the principles of financial statements to provide information about financial position, financial work, cash flow statements. This business will influence the initial capital for the development of the business, and working with bankable is condition discipline. Discipline in terms both business financial records and business legality records.
\end{abstract}

Keywords: Financial Statements, Businessmen, Gresik 


\section{PENDAHULUAN}

Kecamatan Sidayu merupakan salah satu kecamatan dari 18 kecamatan di Kabupaten Gresik. Kecamatan Sidayu merupakan Kadipaten Sedayu yang merupakan Kadipaten bekas Kecamatan Belanda dengan adipati yang dikenal bernama Kanjeng Sepuh Sedayu. Meski hanya sebuah Kecamatan namun Sidayu memiliki bangunanbangunan tua yang cukup megah dan alun-alun yang cukup luas. Kota santri adalah sebutan dari Kecamatan dan sebagai ikon Kabupaten Gresik. Hal ini dikarenakan ratusan pondokan kecil (pesantren anak-anak) tersebar di seluruh penjuru Sidayu. Secara kultural, kehidupan di Sidayu adalah islami secara sosial-masyarakat, ekonomi, politik dan hukum (Sidayu City Explore, tt,a).

Perekonomian daerah ini banyak ditopang oleh sektor ekonomi perdagangan barang dan jasa. Masyarakat Sidayu banyak ditopang oleh sektor wiraswasta, salah satunya industry konveksi/garmen. Hasil utama dari Kecamatan Sidayu ini adalah walet. Selain itu hasil perikanan juga cukup mengalami peningkatan secara signifikan, baik perikanan laut maupun tambak (Sidayu City Explore, tt,b). Salah satu desa yang ikut berperan memajukan kecamatan Sidayu adalah Desa Pengulu dari total 21 desa (Kabupaten Gresik, 2019). Produk unggulan dari desa ini adalah krupuk ikan, bonggolan, minuman temulawak. Usaha tersebut merupakan usaha yang dilakukan untuk meningkatkan sektor produksi UMKM di desa tersebut. Sedangkan hasil tambak yang dibudidayakan adalah bandeng. Namun dalam pembuatan laporan keuangan, masyarakat Desa Pengulu perlu memiliki strategi agar pengeluaran tidak melebihi pendapatan sehingga diharapkan dapat maksimal dan menjadikan perekonomian Desa Pengulu dapat meningkat. Oleh karena itu untuk membantu mengatasi hal tersebut, tim Pengabdian Pada Masyarakat (PPM) Program Studi Manajemen Fakultas Ekonomi Universitas PGRI Adi Buana Surabaya melakukan kegiatan PPM di Desa Pengulu Kecamatan Sidayu Kabupaten Gresik. Diharapkan dengan melakukan kegiatan pengabdian di desa tersebut masyarakat dapat meningkatkan perekonomian desa.

Pengabdian ini dinilai sangat perlu dilaksanakan mengingat masih lemahnya sumber daya manusia, dalam perencanaan pelaksanaan sistem pembuatan laporan keuangan sederhana pada UMKM di desa Pengulu. Beberapa permasalahan yang dapat kami rinci adalah sebahgai berikut :

1. Latar belakang pendidikan pengusaha UMKM yang umumnya masih rendah

2. Belum ada pengalaman dari UMKM dalam pembuatan laporan keuangan.

Kegiatan ini bertujuan untuk menyediakan suatu panduan yang dapat digunakan oleh setiap UMKM untuk membuat laporan keuangan. Panduan sistem akuntansi dan pembuatan laporan keuangan ini akan disususn secara sederhana dan mudah dipahami kalangan pengusaha. Dengan tujuan semua pengguna mudah memanfaatkan penduan penyusunan sistem akuntansi dan penyusunan laporan keuangan khususnya untuk UMKM.

Dengan adanya pengusaha di Desa Pengulu pihak perbankan menawarkan Kredit Usaha Rakyat (KUR) untuk penambahan modal usaha supaya pengusaha ada peningkatan dan termotivasi. Bentuk pinjaman sangat membantu masyarakat yang 
berwirausaha, tanpa menggunakan agunan bunga rendah. Lembaga keuangan mikro ini memberikan pinjaman kepada pengusaha UMKM dengan kredit modal kerja, kredit investasi, kredit konsumtif, kredit eksport impor. Fasilitas kredit yang dipergunakan untuk membiayai kebutuhan modal kerja perusahaan yang pada umumnya berjangka waktu pendek, maksimal satu tahun. Melalaui perancangan ini diharapkan untuk mempermudah UMKM mengetahui posisi kekayaan dan sisa hasil usaha atau mencapai keuntungan yang lebih besar. Usaha ini akan berpengaruh dengan modal awal untuk pengembangan usaha tersebut, dan bekerja sama dengan bankable adalah prasyarat yang dapat diterima oleh bank bila kita ingin berbisnis dengan Bank. Untuk bekerja sama dengan bankable, syaratnya satu yaitu adalah disiplin. Disiplin dalam hal pencatatan baik pencatatan financial usaha maupun pencatatan legalitas usaha. 1) Membuat NPWP, 2) Membuat Surat, 3) Keterangan Usaha, 4) Pencatatan pemasukan dan pengeluaran, 5) Pengarsipan. Buka rekening Bank tabungan atau rekening giro, upayakan keuntungan yang didapat untuk mendapatkan asset, bila memungkinkan menggunakan jasa biro akuntansi untuk mengaudit usaha, dan analisis usaha secara berkala.

Laporan pajak minimal 3 bulan terakhir biasanya digunakan sebagai dasar penilaian usaha. Laporan pajak menunjukkan bahwa usaha tersebut telah melakukan pencatatan transaksi bisnis :

1. Membuat NPWP (Nomor Pokok Wajib Pajak)

Cukup membawa KTP dan syarat lain yang ditentukan Kantor Pajak. Membuat NPWP itu tidak ada biaya yang dikeluarkan, gratis. Untuk UMKM yang menghasilkan produk makanan, status usaha bisa digunakan untuk mendapatkan ijin Pirt sehingga produknya bisa lebih "marketable"

2. Membuat Surat Keterangan Usaha minimal dari Kelurahan,

Setidaknya usaha tersebut sudah tercatat oleh otoritas setempat dan ada ijin operasional. bila memungkinkan sebaiknya ditingkatkan statusnya menjadi TDP, SIUP dan SITU

3. Pencatatat pemasukan dan pengeluaran.

Sediakan beberapa buku tulis untuk mencatat pemasukan dan pengeluaran. Misal, buku penjualan, buku pembelian stok, buku biaya, buku gaji, buku hutang, buku piutang dan buku persediaan. Pengarsipan yang baik, SPK dan DO bisa dijadikan dasar untuk menilai kondite pengusaha.

4. Pengarsipan yang baik.

Sediakan beberapa Block File atau Log File untuk mengarsipkan invoice, tagihan, kwitansi, bukti order, SPK, DO, serta semua kertas atau dokumen yang berhubungan dengan usaha. Upayakan setiap transaksi menggunakan fasilitas jasa bank, hindari transaksi tunai bila memungkinkan.

Keluar masuknya kas secara teratur menjadi bukti arus kas usaha tersebut yang bisa dijadikan penilaian kinerja usaha

5. Buka rekening Bank tabungan atau rekening giro. .

Tabungan diperlukan bila transaksi hanya selalu tunai dengan jumlah kecil dan selalu transfer. Giro diperlukan bila mobilitas cukup tinggi dengan nilai yang cukup tinggi. 
Kelayakan pembelian aset perlu dilakukan agar aset yang dimiliki bisa memberikan nilai (value) bagi usaha.

6. Upayakan keuntungan yang didapat ditabung untuk mendapatkan asset.

Asset bisa berupa mesin, kendaraan, tanah kapling atau rumah. Pengusaha atau pengelola LKM atau UMKM perlu memahami prinsip akuntasi agar usaha tersebut akuntable.

7. Bila memungkinkan dana mencukupi gunakan sofware akuntansi dan gunakan jasa biro akuntansi untuk mengaudit usaha.

Sejumlah dana yang digunakan untuk membiayai operasional perusahaan mulai dari pengadaan bahan (bahan baku/ bahan penolong/ bahan setengah jadi), membiayai tenaga kerja dan biaya overhead pabrik, proses produksi sampai barang tersebut dijual.

Fasilitas Kredit yang ditujukan untuk pembiayaan aktiva tetap dan berjangka waktu panjang ( lebih dari 1 tahun)

1. Investasi baru,peremajaan (penggantian alat), perluasan (pengembangan)

2. Kredit yang diberikan oleh bank dengan maksud untuk memenuhi kebutuhan konsumtif debitur yang didasarkan pada kemampuan debitur dalam mengangsur pokok pinjaman dan bunga dari pendapatan bersih yang diterimanya

3. Fasilitas kredit yang diberikan kepada eksportir/pemasok yang disediakan untuk membiayai seluruh atau sebagian kegiatan produksi, pengumpulan dan atau penyimpanan barang dalam rangka ekspor

4. Fasilitas kredit untuk membiayai seluruh atau sebagian kegiatan dalam rangka impor barang khususnya yang berhubungan dengan L/C impor yang dibuka oleh opening bank (bank penerbit L/C)

5. Pada saat nasabah akan meminjam kredit di Bank maka akan melakukan evaluasi yang meliputi: Penyusunan perjanjian simpan pinjam: penentuan tingkat bunga, plafon kredit,

Monitoring oleh pihak bank: apabila terjadi kredit macet dilakukan restrukturisasi utang atau pelelangan agunan

1. Nasabah meliputi informasi keuangan masa lalu, informasi proyeksi keuangan, deskripsi aset yang dijadikan agunan, detail perencanaan bisnis dan pengalaman manajemen

2. File pihak pemberi dana. Bank menggunakan track record nasabah yang ada di bank pemberi kredit maupun menggunakan data Bank Indonesia melalui BI checking.

3. Asosiasi Bisnis. Asosiasi bisnis bisa memberi informasi mengenai perilaku dan kondisi anggota-anggotanya.

Tahapan dalam proses pemberian pinjaman; persetujuan pinjaman, monitoring pinjaman, pelunasan pinjaman.

Standart penilaian $5 \mathrm{C}$, adalah :

1. Character ; etika terhadap kewajiban/hutang, semangat usaha, aktivitas keagamaan, aktivitas kemasyarakatan, temperamen, keharmonisan keluarga, hubungan dengan tetangga/mitra bisnis 
2. Capacity ; aspek manajemen, aspek pasar dan pemasaran, aspek produksi, aspek keuangan, aspek yuridis, karakteristik manajemen, pengalaman usaha, administrasi usaha, perencanaan bisnis dan operasional, prospek usaha, tingkat persaingan, pasar sasaran, harga produk, sistem pembayaran, sistem distribusi, sumber bahan baku, cara pembelian, proses produksi, mesin dan peralatan, tenaga kerja, dampak sosial dan lingkungan, kemampuan membayar, sitem administrasi dan keuangan, rasio kjeuangan (bila ada), kelengkapan dokumen (ho,npwp,tdp), kepatuhan terhadap regulasi umum \& setempat.

3. Capital; dana sendiri, dana keluarga, dana patungan/join, dana hutang

4. Condition ; Jenis agunan, Kepemilikan, Status Hukum (HM,HGB,HGU), Kondisi Agunan, Jenis Pengikatan

5. Colateral ; kondisi ekonomi pada umumnya, tingkat suku bunga perbankan, inflasi, keterkaitan usaha nasabah/mitra dengan situasi ekonomi makro.

\section{METODE PELAKSANAAN}

Sasaran dari pelatihan ini adalah pengusaha pemula, para wirausahawan, yang bergerak berbasis komunitas yang ada di desa Pengulu dalam skala kecil yang belum mempunyai sistem laporan kuangan sederhana dengan baik. Untuk tahap awal pelaksanaan akan dilaksanakan pada pengusaha :

1. Pengusaha krupuk ikan

2. Pengusaha bonggolan

3. Pengusaha minuman temu lawak

Kegiatan ini memfokuskan pada peningkatan pengetahuan dasar tentang penyusunan laporan keuangan sederhana dan bekerja sama dengan perbankan untuk menambahkan modal usaha. Sasaran kegiatan ini adalah para pengusaha kecil di desa Pengulu Kecamatan Sidayu Kabupaten Gresik, dengan harapan dapat memberikan solusi mengenai perhitungan dan pengelolaan biaya-biaya agar dapat dibuat suatu laporan keuangan yang lebih baik sehingga perekonomian desa dapat meningkat.

Kegiatan pengabdian ini akan menjadi bagian penting Fakultas Ekonomi program Studi Manajemen Universitas PGRI Adi Buana Surabaya.

Metode kegiatan yang dilakukan pada pengabdian ini adalah :

1. Penyusunan proposal pada tahap ini, tim akan melakukan rancangan kegiatan pengabdian yaitu rancangan pembukuan dan format laporan keuangan serta evaluasi yang akan dilakukan.

2. Penyusunan modul dan buku pedoman untuk proses pendampingan.

3. Pelaksanaan simulasi akan dilakukan untuk mengetahui keterbatasan penerapan pembukuan penyusunan laporan keuangan.

4. Pendampingan dilaksanakan dengan materi pembukuan dan penyusunan sistem akuntansi dan keuangan pada pengusaha kecil. Kegiatan ini diharapkan dapat mensosialisasikan hasil simulasi tentang pembukuan dan penyusunan laporan keuangan sebagai wujud pengabdian pada masyarakat. 
Untuk mengetahui wujud keberhasilan pengbdian pada masyarakat, indikasi keberhasilan adalah apabila pengusaha kecil dapat membuat laporan keuangan yang baik dan menyusun laporan sesuai format yang ada. Adapun dokumen pelaksanaan pengabdian pada masyarakat tertera pada gamabar dan tabel dibawah.

\section{HASIL DAN PEMBAHASAN}

Laporan keuangan pengusaha kecil merupakan bagian dari laporan pertanggungjawaban usaha yang nerupakan bagian dari sistem pelaporan keuangan. Untuk mengetahui apakah usaha yang dilakukan pengusaha kecil mengalami perkembangan mendukung pencapain usaha. Standar Akuntansi Keuangan Untuk Entitas Tanpa Akuntabilitas (SAKETAP) adalah ketetapan yang dihasilkan Ikatan Akuntansi Indonesia (IAI) dan diterbitkan tanggal 17 Juli 2009 yang mulai berlaku secara efektif sejak 1 Januari 2011. Standar tersebut dibuat untuk pelaku Usaha Kecil Menengah (UKM) yang ingin menggunakan prinsip laporan keuangan untuk menyediakan informasi tentang posisi keuangan, kierja keuangan, laporan arus kas.

\section{Pengertian laporan keuangan}

1. Laporan keuangan meliputi, laporan posisi keuangan, perhiyungan rugi laba, laporan perubahan posisi keuangan dan catatan atas laporan keuangan.

2. Untuk lebih dekat menggambarkan dan perkembangan perubahan yang dialami perusahaan dai waktu ke waktu sangat dianjurkan menyusun laporan keuangan komperatif setidaknya dua tahun terakhir.

\section{Laporan Perubahan Posisi Keuangan}

Laporan posisi keuangan adalah laporan yang menunjukkan posisi keuangan dari suatu perusahaan pada saat tertentu. Oleh karena itu laporan posisi keuangan harus disusun secara sistematis dengan menggunakan klasifikasi yang sesuai dengan prinsip akuntansi yang belaku umum. Klasifikasi dan penyajian pos-pos dalam laporan keuangan dilakukan sebgai berikut; Aset lancar disajikan sesuai dengan urutan likuiditasnya. Artinya pos yang segera didapat dicairkan menjadi uang tunai disajikan paling atas. Laporan posisi keuangan dapat disusun dengan menggunakan bentuk akun (rekening) atau bentuk laporan . bentuk laporan ini lebih populer karena dapat membandingkan dua buah laporan posisi keuangan atau lebih untuk tahun-tahun yang berurutan.

\section{Penggunaan Arus Kas}

Laporan arus kas dapat disusun dengan menggunakan metode langsung atau metode tidak langsung PSAK no. 2 agar laporan arus kas disusun dengan menggunakan metode langsung. Klasifikasi arus kas bervariasi diantara berbagai negara. Tetapi pada umumnya ada 3 kategori arus kas yaitu 1) arus kas dari aktivitas operasional, 2) arus kas dari aktivitas investasi, dan 3) arus kas dari aktivitas pendanaan (financing). Manfaat yang ingin dicapai dalam pendampingan penyusunan laporan keuangan bagi pengusaha kecil di desa Pengulu adalah :

1. Adanya buku panduan berupa materi penyusunan laporan keuangan sederhana yang menjadi acuan pengusaha. 
2. Adanya peningkatan kemampuan dari pengusaha kecil dalam membuat laporan keuangan tahunan.

3. Pengusaha kecil dapat mengetahui laba rugi usahanya sehingga mempermudah penyusunan dan pembayaran pajak usahanya.

4. Adanya informasi yang akurat bagi pengusaha kecil pihak perbankan dalam pengajuan kredit usaha cara penyusunan laporan keuangan sudah baik.

Kerangka pemecahan masalah sudah dianggap relevan kegiatan ini disusun sedemikian rupa yaitu :

1. Perancangan modul pembukuan dan penyusunan laporan keuangan sederhana.

2. Pembahasan pembukuan dan laporan keuanganyang dibutuhkan UMKM.

3. Pembuatan format pembukuan pendampingan dan laporan keuangan

4. Presentasi di Program Studi Manajemen

5. Perbaikan format modul pembukuan dan laporan keuangan berdasarkan masukan dari rekan-rekan melalui presentasi program studi dari hasil uji coba koperasi toko sebagai sampel.

6. Pendampingan penyusunan laporan keuangan.

\section{Kerja Sama Pengusaha Dengan Bankable}

Usaha ini akan berpengaruh dengan modal awal untuk pengembangan usaha tersebut, dan bekerja sama dengan bankable adalah prasyarat yang dapat diterima oleh bank adalah disiplin. Disiplin dalam hal pencatatan baik pencatatan financial usaha maupun pencatatan legalitas usaha. 1) Membuat NPWP, 2) Membuat Surat, 3) Keterangan Usaha, 4) Pencatatan pemasukan dan pengeluaran, 5) Pengarsipan.

Buka rekening Bank tabungan atau rekening giro, upayakan keuntungan yang didapat untuk mendapatkan asset, bila memungkinkan menggunakan jasa biro akuntansi untuk mengaudit usaha, dan analisis usaha secara berkala.

Tahapan dalam proses pemberian pinjaman; persetujuan pinjaman, monitoring pinjaman, pelunasan pinjaman.

Untuk mengetahui wujud keberhasilan pengbdian pada masyarakat, indikasi keberhasilan adalah apabila pengusaha kecil dapat membuat laporan keuangan yang baik dan menyusun laporan sesuai format yang ada. Adapun dokumen pelaksanaan pengabdian pada masyarakat tertera pada gambar dan tabel dibawah ini.

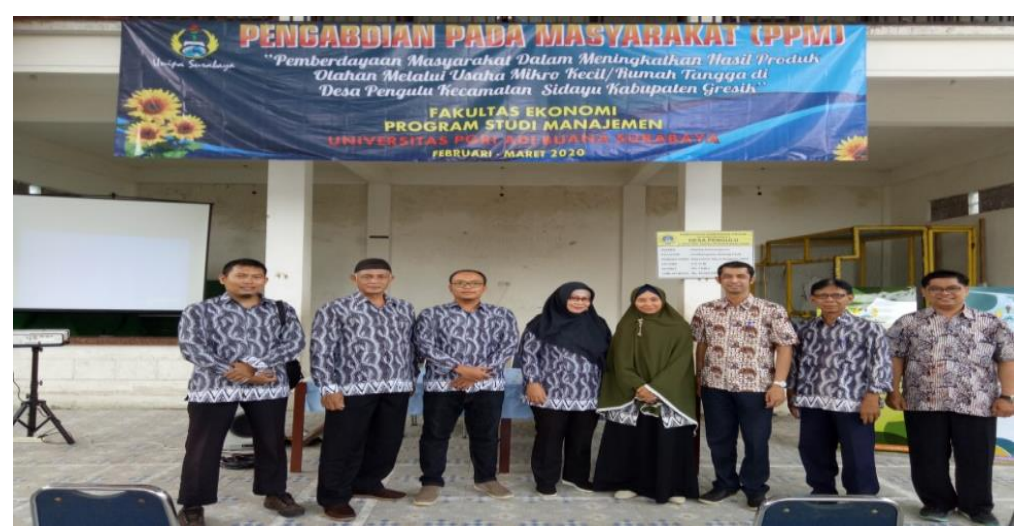

Gambar 1 


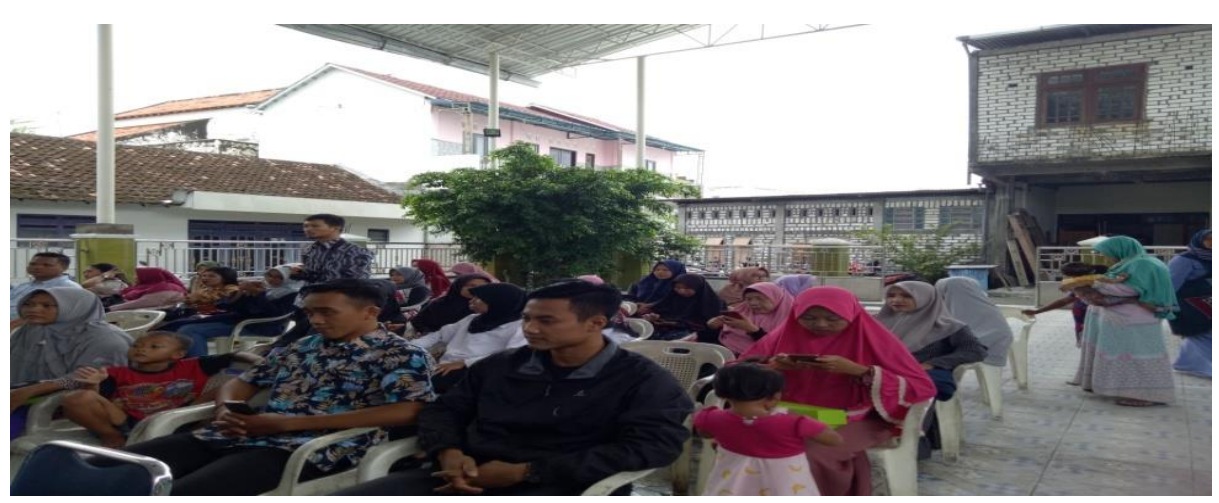

Gambar 2.

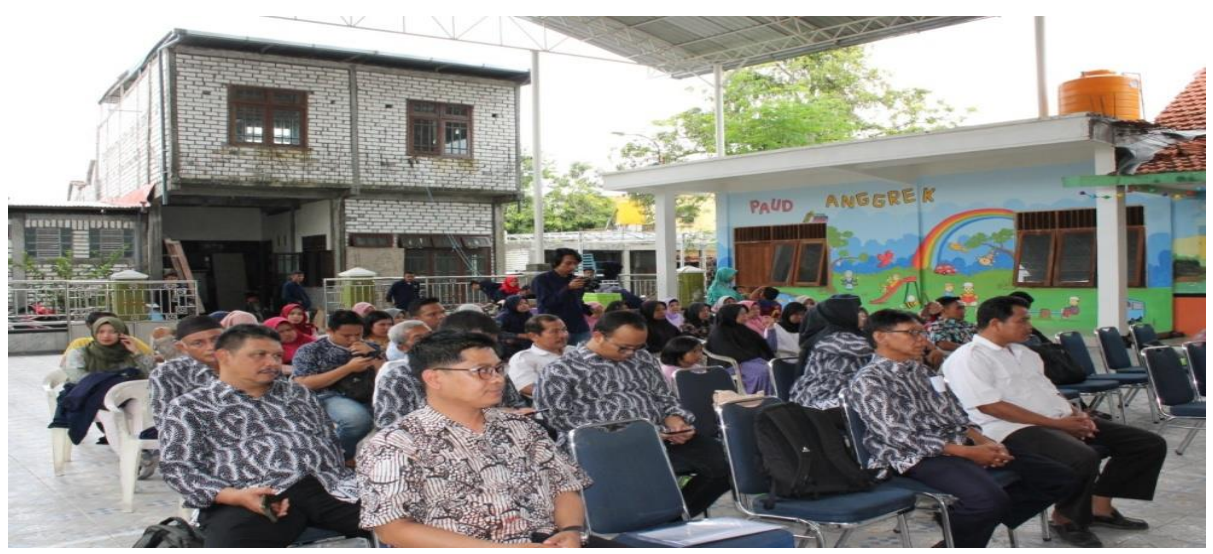

Gambar 3.

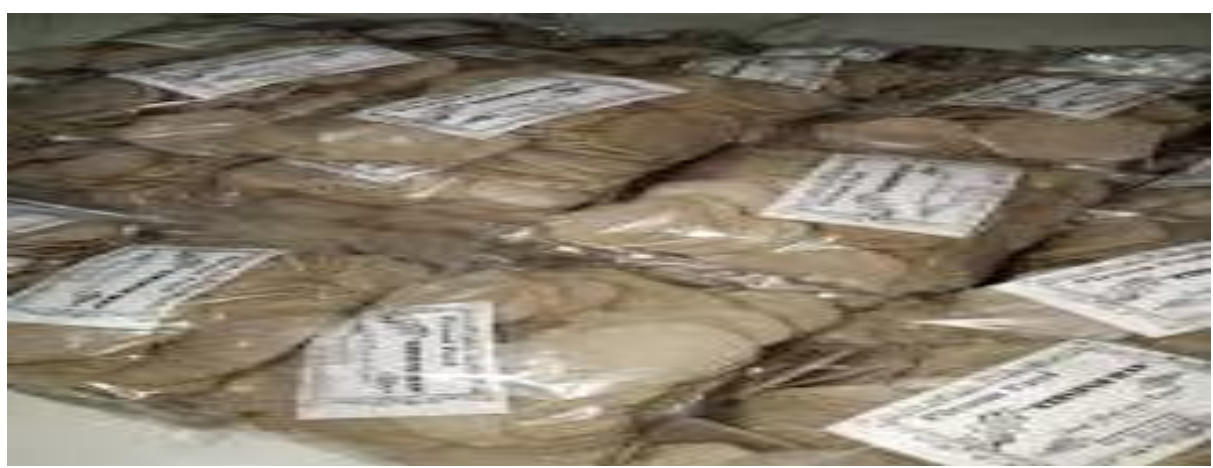

Gambar 4 Hasil Olahan Usaha Kecil

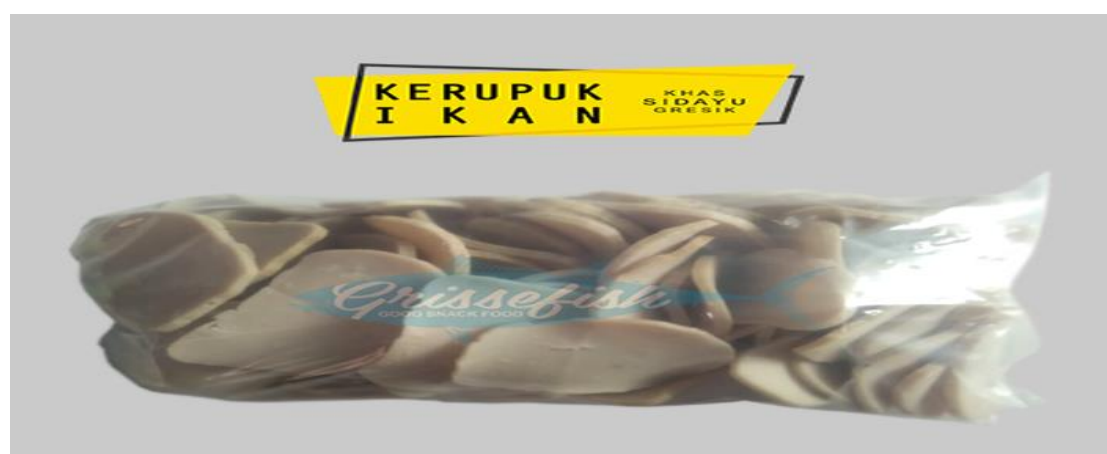

Gambar 5. Hasil Olahan Usaha Kecil 
Tabel 1. Analisa Investasi

\begin{tabular}{ll}
\hline \multicolumn{1}{c}{ Peralatan } & Harga \\
\hline Etalase & Rp. $1.125 .000,-$ \\
\hline Kompor dan Gas & Rp. $190.000,-$ \\
\hline Wajan & Rp. $80.000,-$ \\
\hline Tempat/baskom & Rp. $\quad 70.000,-$ \\
\hline Meja dan kursi & Rp. $800.000,-$ \\
\hline Peraltan tambahan & Rp. $30.000,-$ \\
\hline Jumlah Investasi & Rp. $2.295 .000,-$ \\
\hline
\end{tabular}

Tabel 2. Biaya Opersional Perbulan

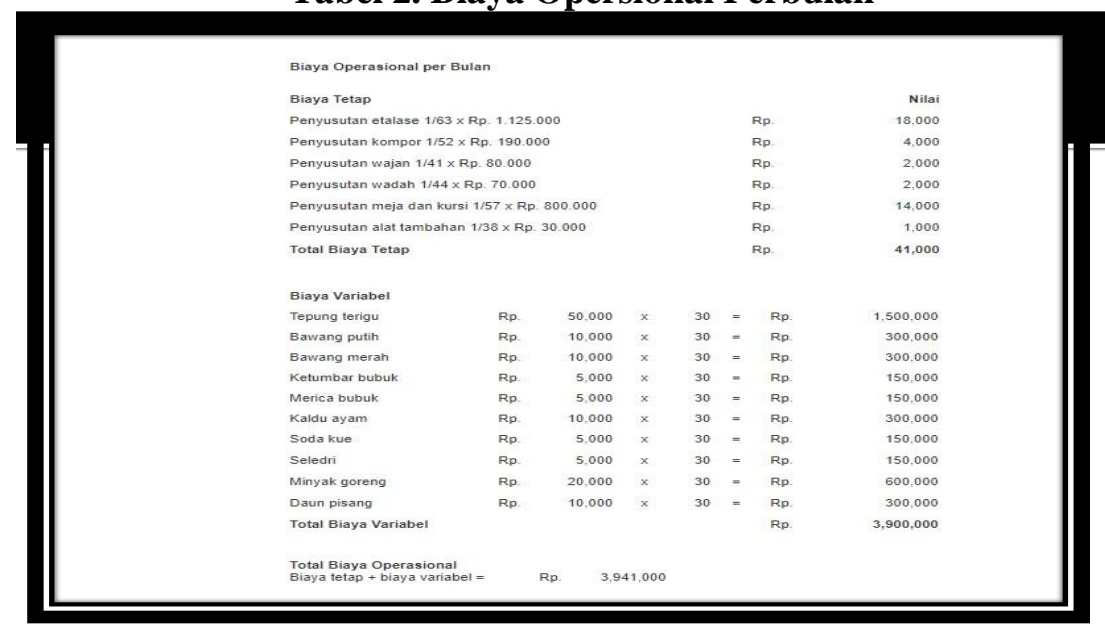

Tabel 3.Laporan Keuangan

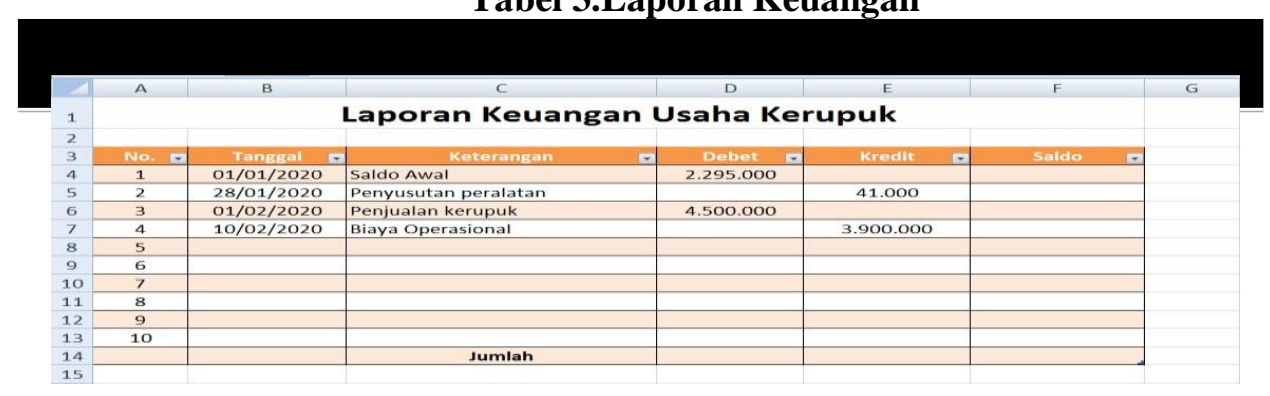

Tabel 4. Pendapatan Perbulan

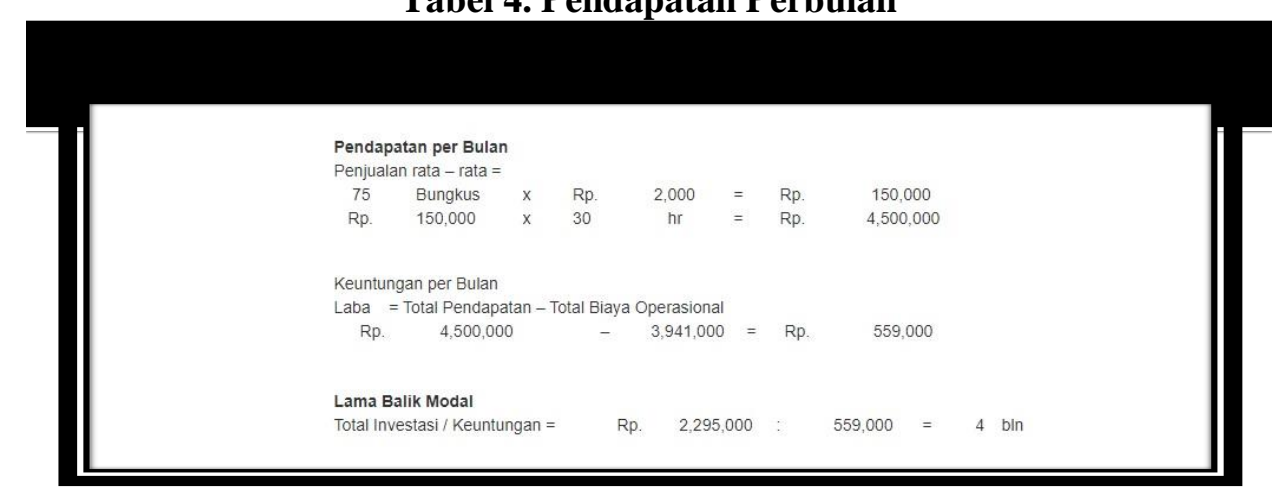




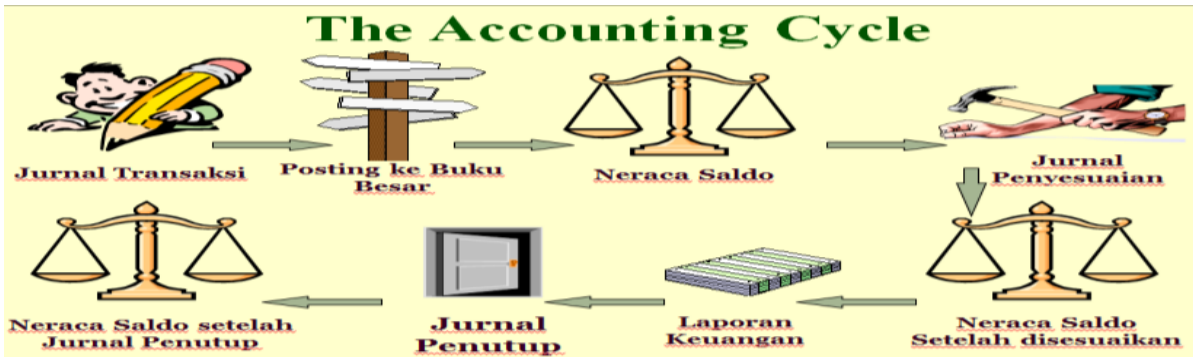

Gambar 6. Usaha Akuntable

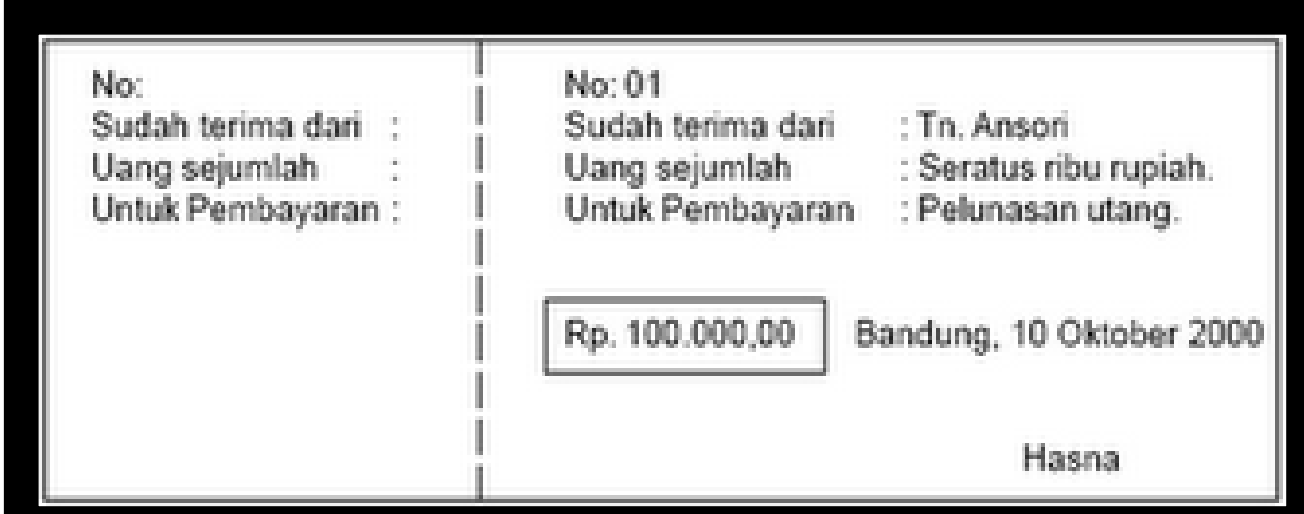

Gambar 7. Contoh Pengarsipan Bukti Transaksi

Tabel 5. Laporan Keuangan

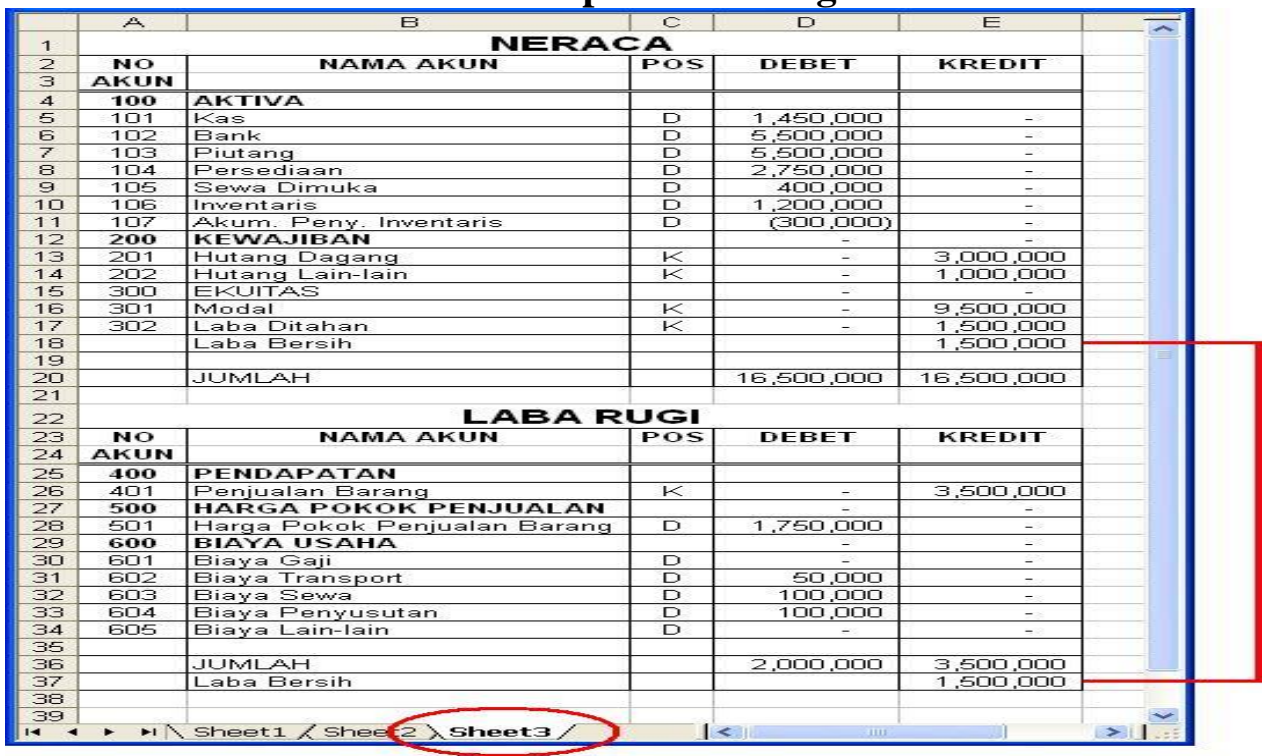

\section{DAMPAK DAN MANFAAT KEGIATAN}

Dampak positif pelaksanaan kegiatan Pengabdian pada masyarakat adalah wajib dilaksanakan karena mengikuti aturan dari Kemenristekdikti, untuk mengembangkan kegiatan dosen akan mendapat nilai yang tinggi. Selain melaksnakan Tri Dharma perguruan tinggi, perkembangan informasi dan komunikasi kepada masyarakat harus ditingkatkan melalui pengabdian tersebut. Dan memotivasi kepada masyarakat yang 
kurang berkembang dengan teknologinya. Oleh karena itu dampak negatifnya bagi dosen yang tidak melaksanakan pengabdian, maka kurang berkembang akan mendapat nilai yang rendah terutama ditingkat Perguruan Tinggi..

Setiap kegiatan yang dilakukan akan membawa manfaat, demikian halnya kegiatan pengabdian kepada masyarakat yang diselenggarakan oleh Tim Program Studi Manajemen Fakultas Ekonomi Universitas PGRI Adi Buana Surabaya. Pengabdian Kepada Masyarakat ini diharapkan membawa peningkatan bagi masyarakat desa Pengulu Kecamatan Sidayu Gresik dalam bidang usaha makanan dan minuman dan mengembangkan laporan keuangan. Apabila sudah mencapai capaiannya maka pengusaha bisa bekerja sama dengan lembaga keuangan diantaranya adalah perbankan. Pihak bank bisa meminjami modal untuk mengembangkan usahanya, supaya komunitas usaha kecil bertambah semangat.

\section{SIMPULAN}

Hasil yang diharapkan dalam pelaksanaan pengabdian adalah tersedianya suatu buku panduan yang memberikan acuan dan metode laporan keuangan yang sederhana serta pendampingan langsung pada pengusaha kecil. Hasil dari laporan keuangan yang disusun dapat berguna bagi pengusaha kesil untuk penilian kinerja sebagai salah satu syarat pertanggungjawaban kepada pihak pajak dan calon kreditur atau ivestor. Pelaku Usaha Kecil Menengah (UKM) yang ingin menggunakan prinsip-prinsip laporan keuangan utnuk menyediakan informasi tentang posisi keuangan, kinerja keuangan, laporan arus kas dan sebaganunya. Menurut standar Akuntansi Keuangan untuk Entitas Tanpa Akuntabilitas Publik (SAKETAP) ketetapan yang dihasilkan Ikatan Akuntansi Indonesia (IAI) diterbitkan pada tanggal 17 Juli 2009 yang mulai berlaku secara efektif sejak tanggal 1 Januari 2011.

Pengabdian ini dilakukan dengan memberikan materi mengenai pentingnya membuat laporan keuangan dan pengetahuan mengenai pembukuan serta manajemen keuangan sederhana. Kegiatan ini diikuti oleh kelompok pengusaha kecil dan warga desa Pengulu yang sudah melakukan usahanya kurang lebih 5 tahun berjalan. Kegiatan pengabdian pada masyarakat ini mengangkat para pengusaha kecil, agar bisa membuat laporan keuangan sederhana dan dipercaya oleh pihak lembaga keuangan dan dipinjami modal untuk mengembangkan usahanya. Usaha ini akan berpengaruh dengan modal awal untuk pengembangan usaha tersebut, dan bekerja sama dengan bankable adalah prasyarat yang dapat diterima oleh bank bila kita ingin berbisnis dengan Bank. Untuk bekerja sama dengan bankable, syaratnya satu yaitu adalah disiplin. Disiplin dalam hal pencatatan baik pencatatan financial usaha maupun pencatatan legalitas usaha.

\section{UCAPAN TERIMA KASIH}

Puji Syukur kehadirat Allah SWT, Alhamdulillah Kami tim dari Universitas PGRI Adi Buana Surabaya terutama bagi Program Studi Manajemen Fakultas Ekonomi yang telah menyelesaikan kegiatan Pengabdian Kepada Masyarakat mengucapkan terima kasih kepada Bupati Gresik, Camat Sidayau, Kepala Desa Pengulu beserta komunitas 
pengusaha kecil dan masyarakat setempat yang telah menerima tim kami untuk melaksanakan Pengabdian Kepada Masyarakat. Semoga tim kami setelah melaksanakan kegiatan ini bisa mensuport kepada masyarakat desa Pengulu, tim kami yang telah memberikan sosialisasi tentang laporan keuangan. Dan memberi semangat kepada pengusaha sampai bekerja sama dengan lembaga keuangan terutama perbankan yang telah memberi kepercayaan kepada tim pengusaha kecil desa Pengulu sampai meminjami modal untuk mengembangkan usahanya.

\section{DAFTAR PUSTAKA}

Kabupaten Gresik, 2019. Desa di Kecamatan Sedayu. https://gresikkab.go.id/ profil/desa_di_kecamatan_sidayu akses 14 Pebruari 2020.

Sidayu City Explore,tt,a. Sejarah Sedayu.https://sedayuexplore. wordpress.com/sejarahsedayu/ akses 13 Pebruari 2020.

Explorasi Sedayu. https://sedayuexplore.wordpress.com/ekplorasi-sedayu/ akses 13 Pebruari 2020.

Ikatan Akuntansi Indonesia, (2011) Pernyataan Standar Akuntansi Keuangan Entitas tanpa Akuntabilitas Publik, Jakarta. 